\title{
On the Pharmacology of Oxidative Burst of Human Neutrophils
}

\author{
R. NOSÁL ${ }^{1}$, K. DRÁBIKOVÁ ${ }^{1}$, V. JANČINOVÁ ${ }^{1}$, T. MAČIČKOVÁ ${ }^{1}$, J. PEČIVOVÁ $^{1}$, \\ T. PEREČKO ${ }^{1}$, J. HARMATHA ${ }^{2}$, J. ŠMIDRKAL ${ }^{3}$
}

${ }^{1}$ Institute of Experimental Pharmacology and Toxicology, Slovak Academy of Sciences, Bratislava, Slovakia, ${ }^{2}$ Institute of Organic Chemistry and Biochemistry, Czech Academy of Sciences, Prague, Czech Republic, ${ }^{3}$ Department of Dairy Fat and Cosmetics, Faculty of Food and Biochemical Technology, University of Chemistry and Technology, Prague, Czech Republic

Received September 4, 2015

Accepted September 25, 2015

\section{Summary}

The effect of three therapeutically used drugs and five polyphenolic compounds on the mechanism of oxidative burst was compared in whole blood and isolated neutrophils at cellular and molecular level. In $10 \mu \mathrm{M}$ concentration, the compounds investigated decreased the oxidative burst of whole blood in the rank order of potency: $\mathrm{N}$-feruloylserotonin $(\mathrm{N}-\mathrm{f}-5 \mathrm{HT})>$ curcumin (CUR) > quercetin (QUER) > arbutin (ARB) > resveratrol (RES) > dithiaden (DIT) $>$ carvedilol (CARV) $>$ brompheniramine (BPA). The ratio between the percentage inhibition of extracellular versus intracellular chemiluminescence $(\mathrm{CL})$ followed the rank order QUER > N-f-5HT > RES > CUR > DIT and is indicative of the positive effect of the compounds tested against oxidative burst of neutrophils, demonstrating suppression of reactive oxygen species extracellularly with minimal alteration of intracellular reactive oxygen species (ROS). Activation of protein kinase $C$ was significantly decreased by DIT, CUR, QUER and $\mathrm{N}-\mathrm{f}-5 \mathrm{HT}$. CARV, DIT, QUER and ARB reduced activated neutrophil myeloperoxidase release more significantly compared with the effect on superoxide anion generation. All compounds tested increased the activity of caspase-3 in cell-free system. It is suggested that other regulatory mechanisms than protein kinase $C$ might participate in the inhibition of neutrophil activation with the compounds tested. Different mechanisms are concerned in controlling the assembly of NADPH oxidase and the regulatory role of calcium ions is suggested. Compounds decreasing the amount of extracellular ROS generation, yet affecting but minimally intracellular ROS generation, are promising for further investigation in vivo.

\section{Key words}

Human neutrophils - Oxidative burst - Chemiluminescence • Protein kinase $\mathrm{C} \bullet$ Apoptosis

\section{Corresponding author}

R. Nosál', Institute of Experimental Pharmacology and Toxicology, Slovak Academy of Sciences, Dubravska 9, 84104 Bratislava, Slovakia. E-mail: radomir.nosal@savba.sk

\section{Introduction}

Professional phagocytic cells play a central role in defending the host against microorganisms by producing reactive oxygen species (ROS) via the NADPH oxidase enzyme complex (Raad et al. 2009). When appropriately stimulated by a variety of agents, they undergo dramatic physiological and biochemical changes. These are resulting in phagocytosis, chemotaxis and degranulation with the activation of ROS production in a metabolic pathway known as the respiratory burst (O'Dowd et al. 2004). These radicals are involved in the elimination of pathogens, however an excessive and/or sustained increase in ROS production has been implicated in the pathogenesis of cancer, diabetes mellitus, atherosclerosis, neurodegenerative diseases, rheumatoid arthritis, ischemia/ reperfusion injury, obstructive sleep apnea, and other diseases (Droge 2002) and result in damage of surrounding tissues (Halliwell and Whiteman 2004, Lonkar and Dedon 2011). The intracellular oxidants fulfill a regulatory role and participate in the initiation

PHYSIOLOGICAL RESEARCH • ISSN 0862-8408 (print) • ISSN 1802-9973 (online)

(c) 2015 Institute of Physiology v.v.i., Academy of Sciences of the Czech Republic, Prague, Czech Republic

Fax +420 241062 164, e-mail: physres@biomed.cas.cz, www.biomed.cas.cz/physiolres 
of neutrophil apoptosis. Protein kinase $\mathrm{C}$ (PKC) is required for full assembly of NADPH oxidase and activation of the respiratory burst in neutrophils (Bertram and Ley 2011). Phorbol esters stimulate the neutrophil respiratory burst through activation of cytosolic protein kinase $\mathrm{C}$, which in turn activates either a regulatory constituent or the NADPH-oxidase directly in the plasma membrane creating an active $\mathrm{O}^{-}$generating system (Cox et al. 1985). Under physiologic conditions, the balance between generation and elimination of ROS maintains the proper function of redox-sensitive signaling proteins. Normally, the redox homeostasis ensures that the cells respond properly to endogenous and exogenous stimuli. However, when the redox homeostasis is disturbed, oxidative stress may lead to aberrant cell death and contribute to disease development (Trachootham et al. 2008). Development and pharmacological use of polymorphonuclear-targeting agents may be a good therapeutic strategy for regulation of polymorphonuclear functions in control of inflammation and tissue injury (Kori et al. 2009). The development of pharmacological procedures to ameliorate undesirable ROS production may become one of the central issues in research on aging and oxidative stress-related diseases in the near future. A number of therapeutically used medicaments and natural products acted not only as extracellular scavengers but they also suppressed intracellular formation of ROS in human neutrophils (Drábiková et al. 2006, 2013, Jančinová et al. 2012a,b, 2015, Nosál' et al. 2006, 2014, 2015, Pečivová et al. 2007, Perečko et al. 2012). Since the optimum therapy is expected to minimize tissue damage without reduction of neutrophil physiological function, separate analysis of extra- and intracellular effects of antioxidants is of particular importance (El-Benna et al. 2010).

The effect of three therapeutically used drugs and five polyphenolic compounds on the mechanism of oxidative burst was compared in whole human blood and isolated neutrophils at cellular and molecular level with respect to the ratio between extra- and intracellular suppression of ROS generation.

\section{Material and Methods}

\section{Chemicals}

Arbutin (hydroquinone $\beta$-D-glucopyranoside), quercetin (2-(3,4-dihydroxyphenyl)-3,5,7-trihydroxy4H-1-benzopyran-4-one, 3, 3', 4',5,6-pentahydroxyflavone,
PMA (phorbol-4 $\beta$-12 $\beta$-myristate- $13 \alpha$ acetate), luminol, isoluminol, superoxide dismutase, dextran (average MW 464,000), luciferase (from firefly Photinus pyralis), gallic acid, cytochalasin B, o-dianosidine and D-luciferin sodium salt were from Sigma Aldrich Chemie $\mathrm{GmbH}$ (Steinheim, Germany), horseradish peroxidase (HRP), catalase, cytochrome $\mathrm{C}$ and Folin Ciocalteu's phenol reagent were purchased from Merck (Darmstadt, German), Lymphoprep (density $1.077 \mathrm{~g} / \mathrm{ml}$ ) from NycomedPharma AS (Oslo, Norway), brompheniramine (BPA): 3-(4-bromophenyl)-N,N-dimethyl-3-pyridin-2-ylpropan-1-amine from Weyth (Austria), carvedilol ( \pm )-[3(9H-carbazol-4-yloxy)-2-hydroxypropyl][2-(2-methoxyphenoxy)ethyl]am from La Roche (Mannheim, Germany), N-feruloylserotonin (N-f-5HT) was isolated from the seeds of Leuzea carthamoides (Wild DC) by solvent extraction (Harmatha et al. 2007). Resveratrol (RES) was prepared by targeted regioselective synthesis purely as transisomer (Šmidrkal et al. 2010). Picolinic acid was purchased from Fluka (Deisenhofen, Germany), and human purified caspase-3 was obtained from Enzo Life Sciences (Lausen, Switzerland). All other chemicals used were of analytical grade and obtained from commercial sources.

\section{Blood collection and neutrophil separation}

Fresh human blood was obtained at the blood bank by venepuncture from healthy male volunteers (aged 20-50 years) who had not received any medication for at least 7 days. It was anticoagulated with $3.8 \%$ trisodium citrate (blood:citrate ratio $=9: 1$ ). The Ethical Committee license for blood sampling was registered at the National Transfusion Service NTS-KRA/2012/SVI. Human neutrophils were isolated from whole blood, as described previously (Jančinová et al. 2009, Nosál' et al. 2011). The blood was gently mixed and erythrocytes were allowed to sediment in $3 \%$ dextran solution by centrifugation $\left(10 \times \mathrm{g}, 25 \mathrm{~min}, 22^{\circ} \mathrm{C}\right)$. The neutrophil suspension was layered on Lymphoprep $(3 \mathrm{ml})$ and centrifuged $\left(500 \times \mathrm{g}, 30 \mathrm{~min}, 22^{\circ} \mathrm{C}\right)$. After hypotonic lysis and centrifugation $\left(500 \times \mathrm{g}, \quad 10 \mathrm{~min}, 22{ }^{\circ} \mathrm{C}\right)$, the neutrophils were resuspended in $\mathrm{Ca}^{2+}-\mathrm{Mg}^{2+}$-free PBS. After counting, they were adjusted to a final concentration of $10^{5}$ cells/ $\mu$ l (Coulter Counter, Coulter Electronics, England) and kept on ice. The final suspension of neutrophils contained more than $96 \%$ of viable cells, as evaluated by trypan blue exclusion and was used within $2 \mathrm{~h}$, as long as the control chemiluminescence remained constant. 
Chemiluminescence (CL) assay of whole blood and isolated neutrophils

The oxidative burst in whole blood was stimulated with phorbolmyristate acetate (PMA $0.05 \mu \mathrm{M})$. CL was measured in $250 \mu \mathrm{l}$ samples consisting of $50 \mu \mathrm{l}$ aliquots that contained blood (50× diluted), luminol $(250 \mu \mathrm{M})$, compounds tested $(10 \mu \mathrm{M})$ and phosphate buffer (Jančinová et al. 2009). Horseradish peroxidase (HRP $8 \mathrm{U} / \mathrm{ml}$ ) was added to the system and maintained a sufficient extracellular peroxidase concentration. The effect of tested compounds on extraand intracellular reactive oxygen species (ROS) production was measured in unstimulated and PMA $(0.05 \mu \mathrm{M})$-stimulated neutrophils $\left(5 \times 10^{5}\right.$ per sample $)$ by isoluminol/luminol-enhanced CL. Extracellular CL was determined in the system containing isoluminol $(5 \mu \mathrm{M})$ and HRP $(8 \mathrm{U} / \mathrm{ml})$. Intracellular CL was measured with luminol in the presence of extracellular scavengers superoxide dismutase $(100 \mathrm{U} / \mathrm{ml})$ and catalase (2000 U/ml) (Drábiková et al. 2009). The CL of both whole blood and isolated neutrophils was evaluated in a microplate luminometer Immunotech LM-01T (Czech Republic) at $37^{\circ} \mathrm{C}$. The data were based on integral values of CL over $3600 \mathrm{~s}$ (whole blood) or $1800 \mathrm{~s}$ (isolated neutrophils) $(\mathrm{RLU} \times \mathrm{s}$; RLU, relative light units).

\section{Protein kinase C activation}

Phosphorylation of protein kinase $\mathrm{C}$ (PKC) isoenzymes $\alpha$ and $\beta$ II was detected (for details see Jančinová et al. 2009). Isolated human neutrophils $\left(5 \times 10^{6}\right)$ were incubated at $37^{\circ} \mathrm{C}$ with tested compounds for $1 \mathrm{~min}$, stimulated with PMA $(0.15 \mu \mathrm{M}, 1 \mathrm{~min})$ and lysed by the addition of solubilization buffer. After sonication on ice, the samples were centrifuged to remove unbroken cells, the supernatant was boiled for $5 \mathrm{~min}$ with sample buffer and the samples were loaded on $9.8 \%$ SDS polyacrylamide gels. Proteins were separated by electrophoresis, transferred to Immobilon-P Transfer Membrane (Millipore Corp., USA). From the two strips taken, one was detected for PKC and the second for $\beta$-actin, which represented the internal control. Membrane strips were blocked for $60 \mathrm{~min}$ with $1 \%$ bovine serum albumin in Tris buffered saline. The membranes were subsequently washed six times with TBS and incubated for $60 \mathrm{~min}$ with the secondary antibody conjugated to horse-radish peroxidase. The activity of horseradish peroxidase was visualized using Enhanced Chemiluminiscence Western Blotting
Detection Reagents (Amersham, UK), followed by autoradiography. The optical density of each PKC band was corrected by the optical density of the corresponding $\beta$-actin band.

\section{Superoxide determination}

Superoxide formation (Pečivová et al. 2007) was measured in isolated human neutrophils as superoxide dismutase inhibitable reduction of cytochrome $C$. The suspension $\left(1 \times 10^{6}\right.$ neutrophils in PBS with $0.9 \mathrm{mmol} / 1$ $\mathrm{CaCl}_{2}, 0.5 \mathrm{mmol} / 1 \mathrm{MgCl}_{2}$ ) was preincubated for $5 \mathrm{~min}$ at $37{ }^{\circ} \mathrm{C}$ with tested compounds $(10 \mu \mathrm{M})$ and subsequently stimulated by PMA $(1 \mu \mathrm{M})$ for $15 \mathrm{~min}$ at $37^{\circ} \mathrm{C}$. Controls were included for the effect of the stimulus of the drugs tested on cytochrome $\mathrm{C}$ reduction. After centrifugation $\left(4200 \times \mathrm{g}\right.$ for $4 \mathrm{~min}$ at $4{ }^{\circ} \mathrm{C}$ ), absorbance was measured at $550 \mathrm{~nm}$ in a microplate spectrophotometer (Labsystem Multiscan RC, MTX Labsystems, Inc., Vienna, Wyoming, USA).

\section{Myeloperoxidase (MPO) release}

For determination of MPO release (Pečivová et al. 2007), neutrophils were preincubated with cytochalasin B $(5 \mu \mathrm{g} / \mathrm{ml})$ for $5 \mathrm{~min}$ at room temperature. Then the neutrophils $\left(2 \times 10^{6} /\right.$ sample $)$ were preincubated with tested compounds $(10 \mu \mathrm{M})$ in a shaker bath at $37^{\circ} \mathrm{C}$ for $5 \mathrm{~min}$, followed by $15 \mathrm{~min}$ exposure to PMA $(1 \mu \mathrm{M})$. The activity of MPO was assayed in the supernatant after centrifugation $\left(983 \times \mathrm{g}\right.$ for $10 \mathrm{~min}$ at $\left.4{ }^{\circ} \mathrm{C}\right)$ by determining the oxidation of o-dianisidine in the presence of hydrogen peroxide in a microplate spectrophotometer (Labsystem Multiscan RC, MTX Labsystems, Inc., Vienna, Wyoming, USA) at $450 \mathrm{~nm}$.

\section{Recombinant caspase-3 activity}

To determine the caspase- 3 activity, a modified method was applied (Perečko et al. 2010). Briefly, the cleavage of the Z-DEVD-amino-luciferin substrate by caspase releases amino-luciferin. The subsequent reaction with luciferase was detected by CL. The light production was measured in the Luminometer Immunotech LM-01T. According to the manufacturer's instructions, $10 \mu \mathrm{l}$ of $0.1 \mathrm{IU}$ caspase was added to $20 \mu \mathrm{l}$ aliquots of tested compounds $(10 \mu \mathrm{M})$ and buffered solution. Finally, $50 \mu \mathrm{l}$ of Caspase-Glo 3/7 Reagent was added and the mixture was measured for $60 \mathrm{~min}$ to determine caspase-3 activity.

\section{Statistical analysis}

Data represent the mean \pm SEM, unless stated 
otherwise. Statistical analysis was performed using the ANOVA paired test to examine differences between the treatments and control. Differences were considered to be statistically significant when $\mathrm{p} \leq 0.05(*)$ or $\mathrm{p} \leq 0.01(* *)$.

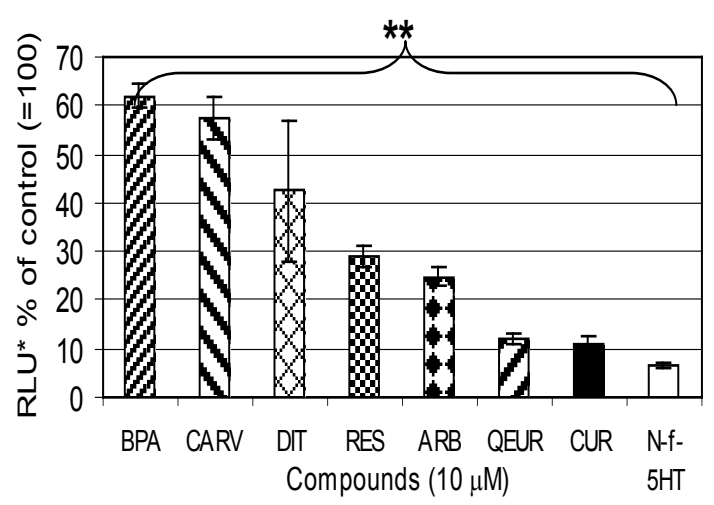

Fig. 1. Effect of the compounds tested on luminol-enhanced chemiluminescence expressed as relative luminescence units (RLU) in whole human blood pretreated with brompheniramine (BPA), carvedilol (CARV), dithiaden (DIT), resveratrol (RES), arbutin (ARB), quercetin (QUER), curcumin (CUR), and $\mathrm{N}$-feruloylserotonin (N-F-5HT) in $10 \mu \mathrm{M}$ concentration and stimulated with phorbolmyristate acetate $(0.05 \mu \mathrm{M}) . \mathrm{n}=6$, $\mathrm{x} \pm \mathrm{SEM}, * * \mathrm{p} \leq 0.01$.

\section{Results}

The effect of the compounds investigated on chemiluminescence (CL) of stimulated whole human blood is shown in Figure 1. In the concentration of $10 \mu \mathrm{M}$, the compounds tested inhibited PMA $(0.05 \mu \mathrm{M})$ stimulated oxidative burst of whole blood in the rank order of potency: N-feruloylserotonin $>$ curcumin $\geq$ quercetin $>$ arbutin $>$ resveratrol $>$ dithiaden $>$ carvedilol $>$ brompheniramine by $93.5,89.9,88.1,75.2,71.0,57.5$, 42.5 and $38 \%$, respectively. The most effective was $\mathrm{N}$-feruloylserotonin, the less potent was brompheniramine.

Figure $2 \mathrm{~A}$ presents the effect of the compounds investigated on extra- and intracellular $\mathrm{CL}$ of isolated human neutrophils exposed to brompheniramine, carvedilol, dithiaden, resveratrol, arbutin, quercetin, curcumin and N-feruloylserotonin in $10 \mu \mathrm{M}$ concentration and subsequently stimulated with PMA $(0.05 \mu \mathrm{M})$. The ratio percentage inhibition between extraand intracellular CL is demonstrated in Figure 2B. It is evident that the most effective for inhibition of extracellular $\mathrm{CL}$ in comparison with intracellular CL inhibition was quercetin (ratio 3.085) followed by $\mathrm{N}$-feruloylserotonin (ratio 2.36) and resveratrol (ratio 1.231). The lowest ratios were found for arbutin (0.183), brompheniramine (0.805) and carvedilol (0.917).

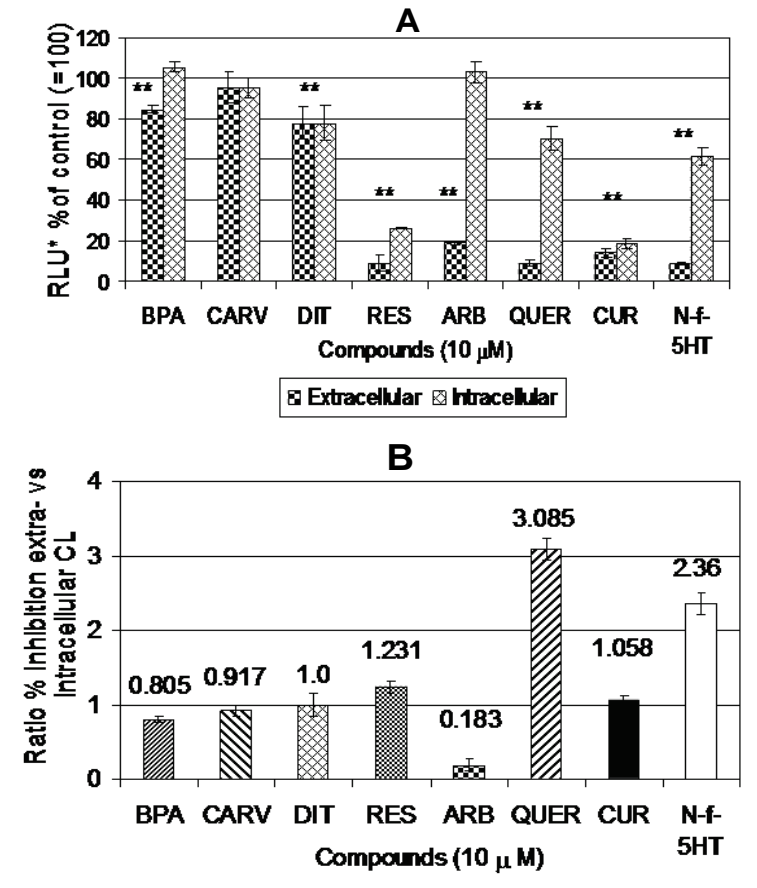

Fig. 2. A. The effect of brompheniramine, carvedilol, dithiaden, resveratrol, arbutin, quercetin, curcumin and $\mathrm{N}$-feruloylserotonin in $10 \mu \mathrm{M}$ concentration on luminol-enhanced extracellular- and isoluminol-enhanced intracellular chemiluminescence (expressed as relative luminescence units - RLU) in isolated human neutrophils stimulated chemiluminescence with phorbolmyristate acetate (PMA $0.05 \mu \mathrm{M}) . \mathrm{n}=6, \mathrm{x} \pm \mathrm{SEM}, * \mathrm{p} \leq 0.05, * * \mathrm{p} \leq 0.01$. B. The ratio between percentage inhibition of extracellular versus intracellular chemiluminescence for brompheniramine (BPA), carvedilol (CARV), dithiaden (DIT), resveratrol (RES), arbutin (ARB), quercetin (QUER), curcumin (CUR) and N-feruloylserotonin $(\mathrm{N}-\mathrm{f}-5 \mathrm{HT})$ in $10 \mu \mathrm{M}$ concentration. Values are calculated from the data in Figure $2 \mathrm{~A}$.

$\mathbf{a}$

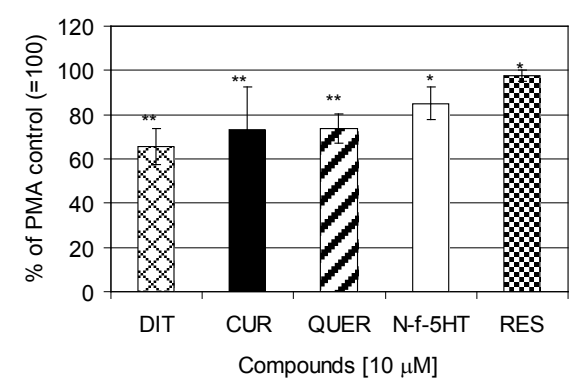

b

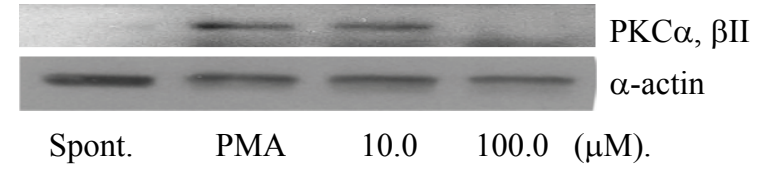

Fig. 3. Protein kinase $C$ activation in isolated human neutrophils exposed to dithiaden (DIT), curcumin (CUR), quercetin (QUER), $\mathrm{N}$-feruloylserotonin (N-f-5HT) and resveratrol (RES) in $10 \mu \mathrm{M}$ concentration and stimulated with PMA $(0.15 \mu \mathrm{M})$. (a) measurements from four experiments, $x \pm S E M, * p<0.05$, ** $\mathrm{p}<0.01$; (b) Representative Western blotting analysis of protein kinase $\mathrm{C}$ activation in isolated human neutrophils pretreated with resveratrol $(10$ and $100 \mu \mathrm{M})$ and stimulated with PMA $(0.15 \mu \mathrm{M})$ (Nosál et al. 2014). 
The effect of the selected compounds dithiaden, curcumin, quercetin, $\mathrm{N}$-feruloylserotonin and resveratrol in $10 \mu \mathrm{M}$ concentration on PMA-activated protein kinase $\mathrm{C}$ in isolated human neutrophils is presented in Figure 3. For resveratrol, the inhibition of PKC activation was dose-dependent. Of the selected compounds, the most effective was dithiaden, followed by curcumin, quercetin, $\mathrm{N}$-feruloylserotonin and resveratrol.

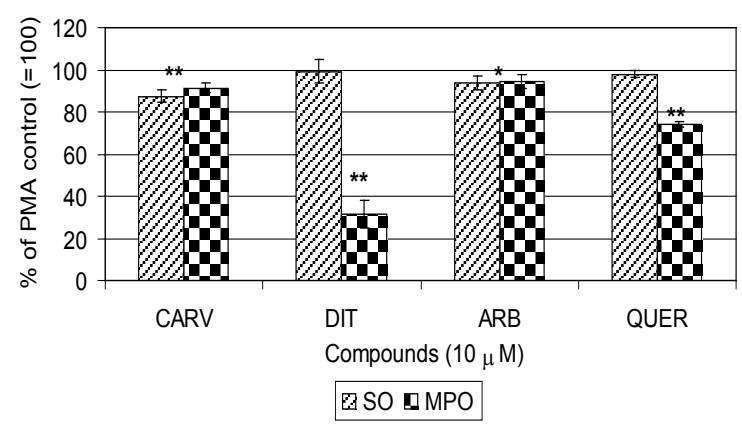

Fig. 4. Generation of superoxide (SO) and liberation of myeloperoxidase (MPO) in isolated human neutrophils treated with carvedilol (CARV), dithiaden (DIT), arbutin (ARB) and quercetin (QUER) in the concentration of $10 \mu \mathrm{M}$ and stimulated with PMA $(1 \mu M) . n=6, x \pm S E M, * p<0.05, * * p<0.01$.

Figure 4 demonstrates the effect of carvedilol, dithiaden, arbutin and quercetin in $10 \mu \mathrm{M}$ concentration on superoxide generation and myeloperoxidase liberation from isolated human neutrophils stimulated with PMA. The most effective for SO inhibition was carvedilol followed by arbutin. Dithiaden and quercetin were ineffective. The most effective for MPO release inhibition was dithiaden followed by quercetin, carvedilol and arbutin.

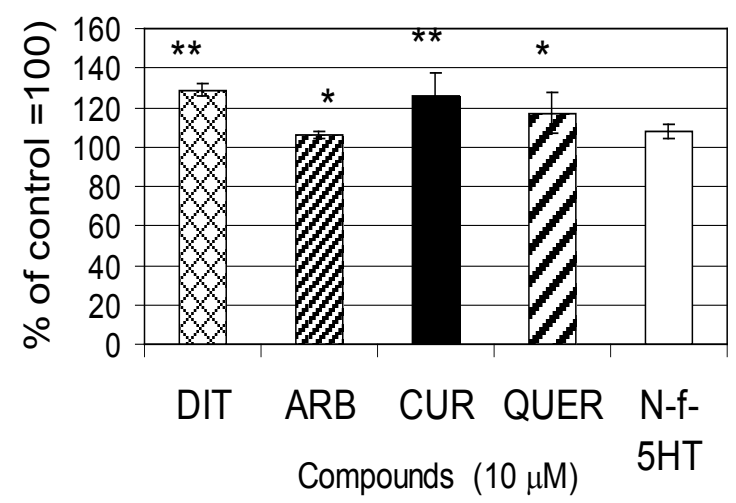

Fig. 5. The effect of dithiaden (DIT), arbutin (ARB), curcumin (CUR), quercetin (QUER) and $\mathrm{N}$-feruloylserotonin (N-f-5HT) in $10 \mu \mathrm{M}$ concentration on caspase-3 activity shown as percentage of control sample (100\%). $n=4-5, x \pm$ SEM, $* p<0.05$, $* * \mathrm{p}<0.01$.
The effect of dithiaden, arbutin, curcumin, quercetin and $\mathrm{N}$-feruloylserotonin in $10 \mu \mathrm{M}$ concentration on human recombinant caspase-3 activity in cell free system is demonstrated in Figure 5. DIT, CUR, QUER, N-f-5HT and ARB increased significantly recombinant caspase- 3 by $28.7,25.7,17.0,7.6$ and $5.8 \%$, respectively.

\section{Discussion}

The results showed that the compounds tested inhibited oxidative burst in stimulated whole human blood as measured by luminol-enhanced chemiluminescence (CL). The inhibition of stimulated chemiluminescence was found to be dose dependent for H1 antihistamines (Nosál' et al. 2015), carvedilol (Nosál' et al. 2005) and many polyphenolic compounds (Jančinová et al. 2012a). Since the generation of reactive oxygen species was induced with PMA bypassing membrane receptors and stimulated protein kinase $C$, the inhibitory effect with three therapeutically used drugs (bromphenyramine, carvedilol and dithiaden) and five polyphenols (arbutin, curcumin, N-feruloylserotonin, quercetin and resveratrol) appeared intracellularly. This was confirmed in isolated neutrophils by measuring the intracellular chemiluminescence (Drábikova et al. 2009) decreasing it in the rank order of potency curcumin $>$ resveratrol $>\mathrm{N}$-feruloylserotonin $>$ quercetin. The intracellular inhibition of luminol-enhanced $\mathrm{CL}$ with antioxidants is dose-dependent and differs for the substances investigated (Nosál' et al. 2015, Jančinová et al. 2012a). On the other hand, all the compounds tested decreased extracellular isoluminol-enhanced $\mathrm{CL}$ corresponding to their scavenging activities for oxidants, most probably as a result of the physico-chemical structure of their molecules, as demonstrated for $\mathrm{H} 1$ antihistamines (Králová et al. 2009). Since intracellular ROS play an important role as regulatory mediators in signaling processes, many of the ROS-mediated responses actually protect the cells against oxidative stress and reestablish redox homeostasis (Droge 2002). PMN functions must be therefore appropriately regulated in order to achieve host defense and avoid tissue-damaging inflammation. Development and pharmacological use of PMN-targeting agents may in fact be a good therapeutic strategy for regulation of PMN functions in control of inflammation and tissue injury (Trachootham et al. 2008, Kori et al. 2009). 
The calculated ratio between the percentage of extra- versus intracellular inhibition of CL indicates that the higher the ratio the lower the risk of the antioxidant tested to suppress intracellular regulatory ROS on the one side while decreasing the risk of extracellular ROS participating substantially in pathological processes (Valko et al. 2007).

Dithiaden, curcumin, quercetin, N-feruloylserotonin and resveratrol decreased the activation of PKC $\alpha, \beta$ indicating interference with PMA activation of the NADPH oxidase system responsible for oxidative burst in neutrophils (Fialkow et al. 2007). The inhibition of PKC $\alpha, \beta$ with several antioxidants in isolated neutrophils was dose-dependent, as found for dithiaden, N-f-5HT, curcumin, pinosylvin and resveratrol (Drábiková et al. 2012, Jančinová et al. 2012a, Nosál' et al. 2011, 2014, 2015).

Protein kinase $\mathrm{C}$ (PKC) involved in the activation of NADPH oxidase in primary neutrophils is activated by exogenous phorbol esters (PMA - Tauber 1987, Dekker et al. 2000, Steinberg 2015). PKC isoforms are important intracellular signaling molecules in cell differentiation, migration, proliferation and activation (Bertram and Ley 2011).

Carvedilol and arbutin slightly decreased superoxide generation in PMA-stimulated neutrophils, dithiaden and quercetin were ineffective. On the other hand, all the compounds tested decreased significantly myeloperoxidase liberation in the same neutrophils with dithiaden being the most active. The kinetic profile of superoxide production varies significantly depending upon the agonists or combination of agonists-antagonists employed. The respiratory burst and production of superoxide in phagocytes is mediated by the NADPHoxidase complex (Robinson 2009).

Neutrophils are the major source of myeloperoxidase in the circulation which is released during the respiratory burst and degranulation process when neutrophils infiltrate tissues. Both SO and MPO are constituents of ROS (Shukla and Walsh 2015).

Dithiaden, curcumin, quercetin and arbutin in concentration of $10 \mu \mathrm{M}$ increased the activity of human recombinant caspase- 3 in cell free system significantly. The effect of $\mathrm{N}$-feruloylserotonin was not significant. The caspase- 3 activity increased with dithiaden was dose- dependent (Nosál' et al. 2015). Caspase-3 belongs to the effector group of caspases which are responsible for the executive phase of apoptosis (Fan et al. 2005). Activation of caspases from their pro-caspase form has been widely described in cells undergoing apoptosis, including neutrophils. Programmed cell death - apoptosis - is an important process for successful removal of recruited neutrophils (Fox et al. 2010, Witko-Sarsat et al. 2011). Activation of recombinant caspase- 3 by the compounds tested might thus contribute to the inhibition of oxidative burst in human neutrophils resulting from suppression of PKC activation and to the antiinflammatory effect of the agents investigated.

An excessive and/or sustained increase in ROS production has been implicated in the pathogenesis of many diseases (Droge 2002). PMN functions must be appropriately regulated in order to achieve host defense and avoid tissue-damaging inflammation. Development and pharmacological use of PMN-targeting agents may therefore be a good therapeutic strategy in regulating PMN functions for control of inflammation and tissue injury (Kori et al. 2009). Polyphenolic compounds have therapeutic value as antioxidants and anti-inflammatory agents in chronic inflammatory epigenetically regulated diseases (Rahman 2008). A growing body of evidence shows that within cells ROS act as secondary messengers in intracellular signaling cascades which induce and maintain the oncogenic phenotype of cancer cells and ROS can also induce cellular senescence and apoptosis and thus function as anti-tumorigenic species (Valko et al.2007). Future studies on the bioavailability, absorption, tissue distribution, and understanding of the in vivo molecular effects of therapeutically used drugs and natural polyphenols are needed in order to consider these compounds as valuable antioxidants and natural therapy 'nutraceuticals' for chronic inflammatory disorders.

\section{Conflict of Interest}

There is no conflict of interest.

\section{Acknowledgements}

This work was supported in part by the project APVV0052-10, APVV-0315-07 of the Slovak Research and Development Agency and by the grant VEGA 2/0010/13.

\section{References}

BERTRAM A, LEY K: Protein kinase C isoforms in neutrophil adhesion and activation Arch Immunol Ther Exp 59: 79-87, 2011. 
COX JA, JENG AY, SHARKEY NA, BLUMBERG PM, TAUBER AI: Activation of the human neutrophil nicotinamide adenine dinucleotide phosphate (NADPH)-oxidase by protein kinase C. J Clin Invest 76: $1932-$ $1938,1985$.

DEKKER LV, LEITGES M, ALTSCHULER G, MISTRY N, MCDERMOTT A, ROES J, SEGAL AW: Protein kinase C-beta contributes to NADPH oxidase activation in neutrophils. Biochem J 347: 285-289, 2000.

DRÁBIKOVÁ K, JANČINOVÁ V, NOSÁL' R, SOLÍK P, MURÍN J, HOLOMÁŇOVÁ D: On the antioxidant activity of carvedilol in human polymorphonuclear leukocytes in vitro and ex vivo. Neuro Endocrinol Lett 27 (Suppl 2): 138-140, 2006.

DRÁBIKOVÁ K, PEREČKO T, NOSÁL R, BAUEROVÁ K, PONIŠT S, MIHALOVÁ D, KOGAN G, JANČINOVÁ $\mathrm{V}$ : Glucomannan reduces neutrophil free radical production in vitro and in rats with adjuvant arthritis. Pharmacol Res 59: 399-403, 2009.

DRÁBIKOVÁ K, PEREČKO T, NOSÁL R, HARMATHA J, ŠMIDRKAL J, JANČINOVÁ V: Polyphenol derivatives - potential regulators of neutrophil activity. Interdisc Toxicol 5: 65-67, 2012.

DRÁBIKOVÁ K, PEREČKO T, NOSÁL' R, HARMATHA J, ŠMIDRKAL J, JANČINOVÁ V: Study of possible mechanisms involved in the inhibitory effects of coumarin derivatives on neutrophil activity. Oxid Med Cell Longev 2013: Article ID 136570, 2013. doi: 10.1155/2013/136570, 10 pages.

DROGE W: Free radicals in the physiological control of cell function. Physiol Rev 82: 47-95, 2002.

EL-BENNA J, DANG PM, PÉRIANIN A: Peptide-based inhibitors of the phagocyte NADPH oxidase. Biochem Pharmacol 80: 778-785, 2010.

FAN TJ, HAN LH, CONG RS, LIANG J: Caspase family proteases and apoptosis. Acta Biochim Biophys Sin (Shanghai) 37: 719-727, 2005.

FIALKOW L, WANG Y, DOWNEY GP: Reactive oxygen and nitrogen species as signaling molecules regulating neutrophil function. Free Radical Biol Med 42: 153-164, 2007.

FOX S, LEITCH AE, DUFFIN R, HASLETT C, ROSSI AG: Neutrophil apoptosis: relevance to the innate immune response and inflammatory disease. J Innate Immunol 2: 216-227, 2010.

HALLIWELL B, WHITEMAN M: Measuring reactive species and oxidative damage in vivo and in cell culture: how should you do it and what do the results mean? Br J Pharmacol 142: 231-255, 2004.

HARMATHA J, BUDEŠÍNSKÝ M, VOKÁČ K, PAVLÍK M, GRUNER K, LAUDOVÁ V: Lignan glucosides and serotonin phenyl-propanoids from the seeds of Leuzea carthamoides. Coll Czechoslov Chem Commun 72 : 334-346, 2007.

JANČINOVÁ V, PEREČKO T, NOSÁL' R, KOŠTÁLOVÁ D, BAUEROVÁ K, DRÁBIKOVÁ K: Decreased activity of neutrophils in the presence of diferuloylmethane (curcumin) involves protein kinase C inhibition. Eur $J$ Pharmacol 612: 161-166, 2009.

JANČINOVÁ V, PEREČKO T, HARMATHA J, NOSÁL' R, DRÁBIKOVÁ K: Decreased activity and accelerated apoptosis of neutrophils in the presence of natural polyphenols. Interdisc Toxicol 5: 59-64, 2012a.

JANČINOVÁ V, PEREČKO T, NOSÁL' R, HARMATHA J, SMIDRKAL J, DRÁBIKOVÁ K: The natural stilbenoid pinosylvin and activated neutrophils: effects on oxidative burst, protein kinase $\mathrm{C}$, apoptosis and efficiency in adjuvant arthritis. Acta Pharmacol Sin 33: 1285-1292, 2012 b.

JANČINOVÁ V, PAŽOUREKOVÁ S, LUCOVÁ M, PEREČKO T, MIHALOVÁ D, BAUEROVÁ K, NOSÁL R, DRÁBIKOVÁ K: Selective inhibition of extracellular oxidants liberated from human neutrophils. A new mechanism potentially involved in the anti-inflammatory activity of hydroxychloroquine. Int Immunopharmacol 28: 175-181, 2015.

KORI S, NAMIKI H, SUZUKI K: Biphasic regulation of polymorphonuclear leukocyte spreading by polyphenolic compounds with pyrogallol moieties. Int Immunopharmacol 9: 1159-1167, 2009.

KRÁlOVÁ J, RAČKOVÁ L, PEKAROVÁ M, KUBALA L, NOSÁL' R, JANČINOVÁ V, ČÍŽ M, LOJEK A: The effects of H1-antihistamines on the nitric oxide production by RAW 264.7 cells with respect to their lipophilicity. Int Immunopharmacol 9: 990-995, 2009.

LONKAR P, DEDON PC: Reactive species and DNA damage in chronic inflammation: reconciling chemical mechanisms and biological fates. Int J Cancer 128: 1999-2009, 2011. 
NOSÁL' R: Antiplatelet and antileukocyte effects of cardiovascular, immunomodulatory and chemotherapeutic drugs. Cardiovasc Hematol Agents Med Chem 4: 237-261, 2006.

NOSÁL' R, JANČINOVÁ V, ČÍŽ M, DRÁBIKOVÁ K, LOJEK A, FÁBRYOVÁ V: Inhibition of chemiluminescence by carvedilol in the cell-free system, whole human blood and blood cells. Scand J Clin Lab Invest 65: 55-64, 2005.

NOSÁL' R, PEREČKO T, JANČINOVÁ V, DRÁBIKOVÁ K, HARMATHA J, SVITEKOVÁ K: Naturally appearing $\mathrm{N}$-feruloylserotonin isomers suppress oxidative burst of human neutrophils at the protein kinase $\mathrm{C}$ level. Pharmacol Rep 63: 790-798, 2011.

NOSÁL R, DRÁBIKOVÁ K, JANČINOVÁ V, PEREČKO T, AMBROŽOVÁ G, ČÍŽ M, LOJEK A, PEKAROVÁ M, ŠMIDRKAL J, HARMATHA J: On the molecular pharmacology of resveratrol on oxidative burst inhibition in professional phagocytes. Oxid Med Cell Longev 2014: Article ID 706269, 2014. doi: 10.1155/2014/706269, 9 pages.

NOSÁĹ R, JANČINOVÁ V, DRÁBIKOVÁ K, PEREČKO T: Molecular pharmacology of antihistamines in inhibition of oxidative burst of professional phagocytes. Gen Physiol Biophys 34: 209-216, 2015.

O'DOWD YM, EL-BENNA J, PERIANIN A, NEWSHOLME P: Inhibition of formyl-methionyl-leucyl-phenylalaninestimulated respiratory burst in human neutrophils by adrenaline: inhibition of phospholipase $\mathrm{A}_{2}$ activity but not p47phox phosphorylation and translocation. Biochem Pharmacol 67: 183-190, 2004.

PEČIVOVÁ J, MAČICCCKOVÁ T, LOJEK A, GALLOVÁ L, ČÍŽ M, NOSÁL' R, HOLOMÁŇOVÁ D: In vitro effect of carvedilol on professional phagocytes. Pharmacology 79: 86-92, 2007.

PEČIVOVÁ J, NOSÁL' R, SVITEKOVÁ K, MAČIČKOVÁ T: Arbutin and decrease of potentially toxic substances generated in human blood neutrophils. Interdisc Toxicol 7: 195-200, 2014.

PEREČKO T, DRÁBIKOVÁ K, RAČKOVÁ L, ČÍŽ M, PODBORSKÁ M, LOJEK A, HARMATHA J, ŠMIDRKAL J, NOSÁL' R, JANČINOVÁ V: Molecular targets of the natural antioxidant pterostilbene: effect on protein kinase C, caspase-3 and apoptosis in human neutrophils in vitro. Neuro Endocrinol Lett 31 (Suppl 2): 84-90, 2010.

PEREČKO T, DRÁBIKOVÁ K, NOSÁL' R, HARMATHA J, JANČINOVÁ V: Involvement of caspase-3 in stilbene derivatives induced apoptosis of human neutrophils in vitro. Interdisc Toxicol 5: 76-80, 2012.

RAAD H, PACLET MH, BOUSSETTA T, KROVIARSKI Y, MOREL F, QUINN MT, GOUGEROT-POCIDALO MA, DANG PM, EL-BENNA J: Regulation of the phagocyte NADPH oxidase activity: phosphorylation of gp91phox/NOX2 by protein kinase $\mathrm{C}$ enhances its diaphorase activity and binding to Rac2, p67phox, and p47phox. FASEB J 23: 1011-1022, 2009.

RAHMAN I: Dietary polyphenols mediated regulation of oxidative stress and chromatin remodeling in inflammation. Nutr Rev 66 (Suppl 1): S42-S45, 2008.

ROBINSON JM: Phagocytic leukocytes and reactive oxygen species Histochem Cell Biol 131: 465-469, 2009.

SHUKLA J, WALSH SW: Neutrophil release of myeloperoxidase in systemic vasculature of obese women may put them at risk for preeclampsia. Reprod Sci 22: 300-307, 2015.

STEINBERG SF: Mechanisms for redox-regulation of protein kinase C. Front Pharmacol 128: 1-9, 2015.

ŠMIDRKAL J, HARMATHA M, BUDĚŠINSKÝ M, VOKÁČ K, ZÍDEK Z, KMONÍČKOVÁ E, MERKL R, FILIP V: Modified approach for preparing (E)-stilbens related to resveratrol, and evaluation of their potential immunobiological effects. Coll Czechoslov Chem Commun 75: 175-186, 2010.

TAUBER AL: Protein kinase C and the activation of the human neutrophil NADPH-oxidase. Blood 69: 711-720, 1987.

VALKO M, LEIBFRITZ D, MONCOL J, CRONIN MT, MAZUR M, TELSER J: Free radicals and antioxidants in normal physiological functions and human disease. Int J Biochem Cell Biol 39: 44-84, 2007.

WITKO-SARSAT V, PEDERZOLI-RIBEIL M, HIRSCH E, SOZZANI S, CASSATELLA MA: Regulating neutrophil apoptosis: new players enter the game. Trends Immunol 32: 117-124, 2011. 